\title{
Effectiveness of Alternative Conservation Means in Protecting the Osun-osogbo Sacred Grove in South-West, Nigeria
}

\author{
Adesoji Akinwumi Adeyemi*, Tolulope Hannah Oyinloye \\ Department of Forest Resources Management, Faculty of Agriculture, University of Ilorin, Ilorin, Nigeria \\ Email address: \\ adeyemi.aa@unilorin.edu.ng (A. A. Adeyemi), adeyemiadesoji@yahoo.com (A. A. Adeyemi) \\ ${ }^{*}$ Corresponding author
}

\section{To cite this article:}

Adesoji Akinwumi Adeyemi, Tolulope Hannah Oyinloye. Effectiveness of Alternative Conservation Means in Protecting the Osun-osogbo Sacred Grove in South-West, Nigeria. Plant. Vol. 8, No. 1, 2020, pp. 1-9. doi: 10.11648/j.plant.20200801.11

Received: December 27, 2019; Accepted: January 7, 2020; Published: January 17, 2020

\begin{abstract}
Osun-Osogbo Grove has great cultural histories, but the impacts on biodiversity conservation are hardly captured with many of the component parts unreported. Adequate knowledge of the effectiveness of these traditional means as a sustainable alternative to failed-conventional engagements is worthwhile. Therefore, we investigated some cultural norms, beliefs and traditions and their effectiveness in adequately protecting biodiversity in the grove. Purposive sampling technique was adopted for questionnaire administrations on staff, tourists and the households in the surrounding communities. Three sets of questionnaires were administered on the local residents, staff and custodians of the grove as well as the grove management and custodians. Information was obtained on traditional laws and taboos associated with the grove, and their effectiveness. The coordinates of the referenced cultural values were taken using a GPS receiver Photographs of all relevant features were also taken to substantiate key observations. The taboos identified within the site were farming, killing of animals, fishing, felling of trees, and pollution of the environment and unauthorized building of structures. Tourists' visitations to OOSG were age, gender, religion and education-level dependent. The traditional norms and customs were found to be very potent in protecting the area over conventional laws.
\end{abstract}

Keywords: Traditional Means, Culture, Taboos, Community Participation

\section{Introduction}

In most part of Africa, especially the east and west, and beyond, most local communities have been described as willing to support conservation efforts, hence are rich in biodiversity, only if this agrees with cultures and traditions of people, and their beliefs in natural resources conservation and use $[1,2]$. Traditional knowledge is still very prominent in most remote areas, where decisions about exploitation of local natural resources are heavily-influenced by traditional authorities. In some cases, the exploitation of species that have a material or spiritual relationship with the community is often regulated [3]. Culture is that complex whole, which includes knowledge, belief, art morals, laws; customs and any other capabilities and habits acquired by man as members of his society [4]. It is a component of accumulated resources, which could be immaterial as well as material, that people inherit, employ, transmute, add to and transmit [5]. The long-time span of culture qualifies it as a heritage. Sacred forests are sites of cultural or spiritual significance for the people, who live around them. Grove will remain a living thriving heritage that has traditional landmarks and a veritable means of transfer of traditional religion, and indigenous knowledge systems to African people [6]. They exist around the world and represent a long-held tradition of community forest management. Grove also serves as a model of African heritage that preserves the tangible and intangible values of the people. Cultural values and social constructions of nature and landscape are at the centre of relationships between nature and communities. Culture might favour biodiversity conservation in the short term, in the long term, such strategy may fail to preserve biodiversity if the authorities disregard the importance of simultaneously promoting active local community participation in protected 
area management, capacity building, implementing adequate outreach programmes, and also efficient governance, guaranteeing that penalties will be applied and consistently enforced [7]. Moreover, different people, have different values and even value, and may view the same object differently. Sacred groves, throughout the world, are associated with a range of traditional and cultural values related to forests, rituals and taboos.

Osun-Osogbo Grove is among the last of the sacred forests, which usually adjoined the edges of most Yoruba cities before extensive urbanization [8] and civilization. The grove is regarded as the abode of the Osun goddess of fertility, who was one of the pantheons of Yoruba gods. The grove is seen and regarded as a symbol of identity for the Yoruba race, and probably the last of its kind in Yoruba culture. The grove has a mature, reasonably undisturbed, forest canopy, which supports a rich and diverse flora and fauna including the vulnerable white-throated monkey. The grove was designated a world heritage site by UNESCO on $15^{\text {th }}$ July, 2005 in recognition of its global importance and cultural value [9]. Although Osun-Osogbo Grove is known to have many traditional histories and cultural heritage, little is documented about the cultural values, their significance and their geographical references within the sites. Consequently, many were not aware of the significance of the cultural norms in the grove, and information about "do and don't" in the area are not available beyond the boundaries of the grove.

Universal Declaration on Cultural Properties Diversity and the Convention on the Protection and Promotion of the Diversity of Cultural Expressions, included that the recognition of the importance of cultural diversity as an essential component in the development and implementation of approaches to manage the social, economic, and cultural impacts of globalization on contemporary cultural expressions, as well as cultural heritage $[10,11]$. There is, therefore, the need to investigate the cultural values and their significance in the sacred grove in order to explore the possibilities in other conservation areas requiring such an interventions in Nigeria. Documenting cultural values of the Osun-Osogbo sacred grove will help in providing useful information about the existence, traditional taboos and laws associated with the grove and their management.

\section{Methodology}

\subsection{The Study Area}

Osun-Osogbo Sacred Grove is located along the bank of Osun River in Osogbo Local Government Area of Osun State in South-western Nigeria. It is situated approximately between latitudes $7^{\circ} 44^{\prime} 50.0^{\prime \prime}$ and $7^{\circ} 46^{\prime} 00.0^{\prime \prime} \mathrm{N}$, and longitudes $4^{\circ} 32^{\prime} 40^{\prime \prime}$ and $4^{\circ} 33^{\prime} 40^{\prime \prime} \mathrm{E}$ (Figure 1). The sacred grove is located on the margin of the southern forests of Nigeria on a raised parcel, which is about $350 \mathrm{~m}$ above sea level. The grove is bounded in the North by Laro and Timehin Grammar Schools, in the South by entrance of Ladoke Akintola University of Technology (LAUTECH), which runs parallel to form a western boundary. In the east, it is bounded by Osun State Agricultural Farm Settlements [12]. It covers an area of 75 ha and is encircled by a buffer zone of 47 ha [13].

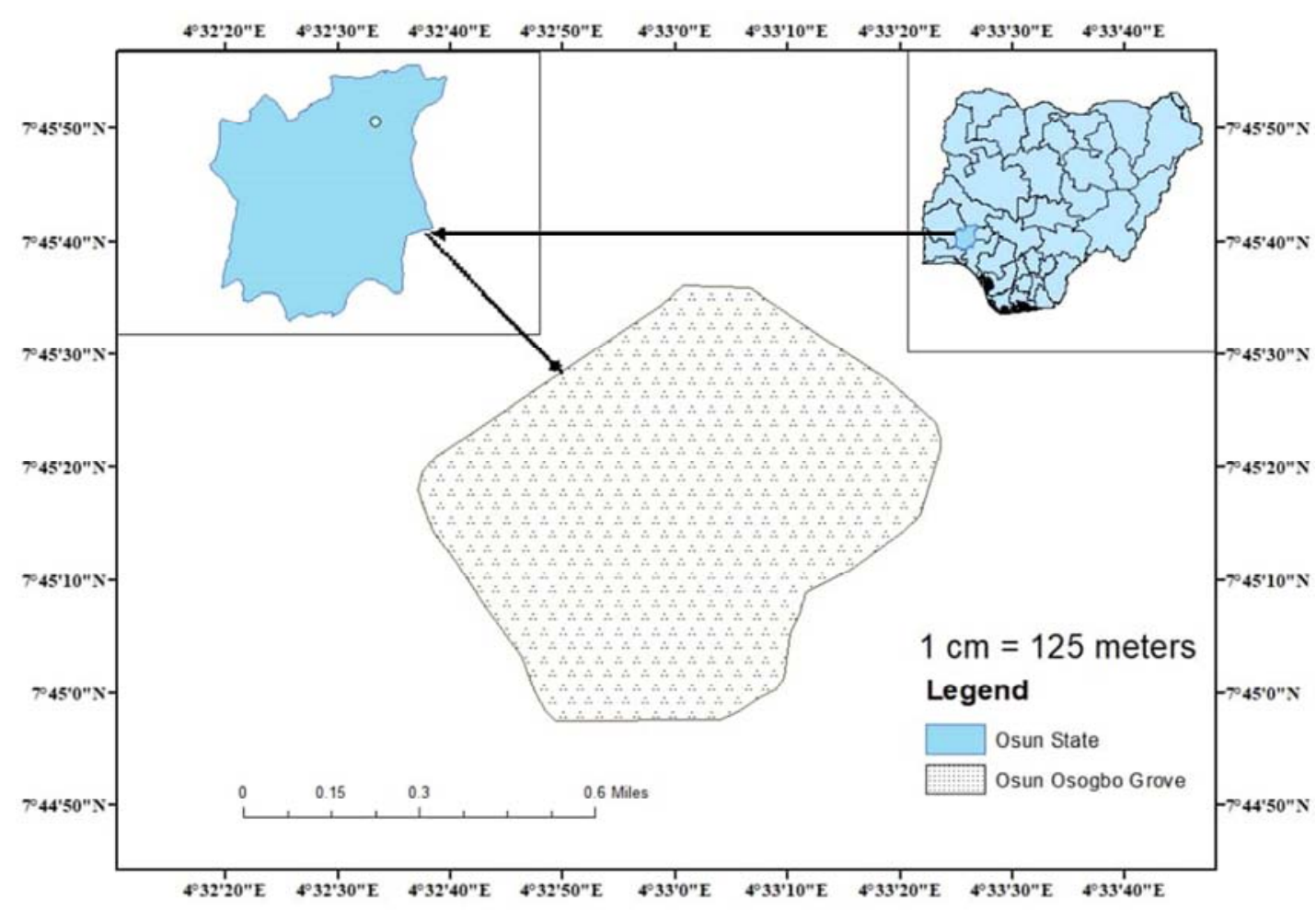

Figure 1. Map of the study area. 


\subsection{Climate and Soil}

The area is characterized by high humidity and annual rainfall of between $1200 \mathrm{~mm}$ and $1450 \mathrm{~mm}$. Annual temperature is between $22^{\circ} \mathrm{C}$ and $35^{\circ} \mathrm{C}$. The relative humidity of the area is between $92 \%$ and $99 \%$ [14]. It is contained within the rainforest zone of Nigeria with an area of undisturbed primary tropical dense forest ecosystem in the north central and southern part and mangrove in the east. The two main seasons (dry and rainy) generally observed within Osun State is typical of the grove. The rainy season is between March and October with double peaks in May/June and October/November. The microclimate within the grove is more humid than it is in a greater part of southern Nigeria [15]. However, considerable stretches (buffers) of the original forest have now been replaced by secondary forest [16]. The soils are of depositional nature towards the riverbanks and at the lower slopes. Occasionally, the soils formed at the summit of the hill could be seen (especially on Adunni Hill). The river drains the Osun basin in a north-south direction and passes out of the grove south-westwards. The underlying rocks at the river bed are of Precambrian formation. They are uncovered in some parts of the grove during the dry season, when the river cuts into pools/lakes within the banks. The soil of the grove is generally acidic containing low nutrient reserves 4.2-6.9.

\subsection{Sampling Procedure and Data Collection}

Purposive sampling technique was adopted for questionnaire administrations on staff, custodian, tourists and the indigenous communities. Information on the traditional laws and taboos associated with the management and protection of the grove as well as the effectiveness of the traditional means in preserving the grove were gathered using a semi-structured questionnaire. 300 copies of questionnaires were administered to tourists and the households in communities around the grove. Global positioning system (GPS) receiver was used to obtain the coordinates of all the cultural values and other important areas within the grove for mapping. Photographs of all relevant features were also taken to substantiate key observations. Another set of questionnaire was used to obtain information from the custodian, staff and management in-charge of the grove on the potency of the cultural means in conserving the biodiversity in the area. Data were analyzed using descriptive statistics. These include perception of respondents about the traditional laws and taboos associated with the study area. Chi-square test of equal probability was used in analyzing some of the responses regarding the effectiveness of cultural norms in conserving flora and fauna diversities in the area.

\section{Results}

\subsection{Identified Taboos Associated with the Grove}

The result showed that hunting of animals, felling of trees, farming, fishing, water pollution using chemicals and erection of unauthorized structures are prohibited with grave consequences for offenders (Table 1). It was further revealed that anyone, who violates the traditional laws faces death, wrath of the goddess/flooding, imbecility or insanity and unproductiveness, irrespective of gender or race. However, sanctions based on conventional laws are lighter, and do not deter potential offenders from commission.

Table 1. Identified taboos associated with the grove.

\begin{tabular}{lll}
\hline Taboo & Consequence (traditional norm) & Sanction (conventional law) \\
\hline Hunting/Killing of animals & Death & Payment of fine or one-month jail term \\
Felling of trees & Wrath of the Osun goddess/ Flood & Payment of fine or one-month jail term \\
Farming & Unproductiveness & Payment of fine or Jailed for one month \\
Fishing & Imbecility or insanity & Payment of fine or one-month jail term \\
Water pollution & Wrath of the Osun goddess & Payment of fine or one-month jail term \\
Building of unauthorized structures & Wrath of the Osun goddess & Removal of building and Payment of fine \\
\hline
\end{tabular}

\subsection{Effectiveness of Traditional Laws in Conserving the Sacred Grove}

The perception of the respondents on the level of effectiveness of the traditional norms at the site is presented in Table 2. About $78 \%$ of the respondents were of the opinion that the traditional laws were highly effective for conservation of the grove, while $22 \%$ believed the effectiveness of the norms. None of the respondents doubted the effectiveness of the traditional norms in protecting the area.

Table 2. Level of effectiveness of the traditional norms/taboos in the grove.

\begin{tabular}{lllll}
\hline Effectiveness & Frequency & \% & df & P-value \\
\hline Effective & 67 & 22 & 2 & 0.003 \\
Highly effective & 233 & 78 & & \\
\hline
\end{tabular}

\begin{tabular}{lllll}
\hline Effectiveness & Frequency & $\%$ & df & P-value \\
\hline Not effective & - & - & & \\
Total & 300 & 100 & & \\
\hline
\end{tabular}

$\alpha=0.05$.

As shown in Table 3, 72\% of the tourist interviewed confirmed that management of the grove was very good, while $28 \%$ said that the level of management was good.

Table 3. Level of the management of the grove as perceived by tourists.

\begin{tabular}{lllll}
\hline Management & Frequency & \% & df & P-value \\
\hline Very good & 215 & 72 & 2 & 0.000 \\
Good & 85 & 28 & & \\
Poor & - & - & & \\
Total & 60 & 100 & & \\
\hline
\end{tabular}

$\alpha=0.05$. 
Osun-Osogbo Sacred Grove is mainly dominated by vegetation with the remaining parts as bare lands (due to inflows of visitors) and water body. Most of the cultural values identified in the sacred grove are located under vegetation. They include sculpture of Yemoo, Iyana Arugba, the flying tortoise Egungun, Lajomi, Kanmololu, Oguntimeyin, Pajepolobi, Arenugbongi, Eyefodo (Ile eleye), Egun meta,
Iya Osun, Baba Osun, Osun, Opelebapelepo, Arugba, Atupa Olojumerindinlogun, Olomoyoyo, Ela, Sanpoona. Beside the Osun River is the Osun Shrine, close to the shrine is Oke Shrine, Egbe Shrine, Obaluaye Shrine, Ogun Shrine and also the First Palace. The Divination Forest (Igbo Ifa) is mainly dominated by vegetation (Table 4, Figure 2).

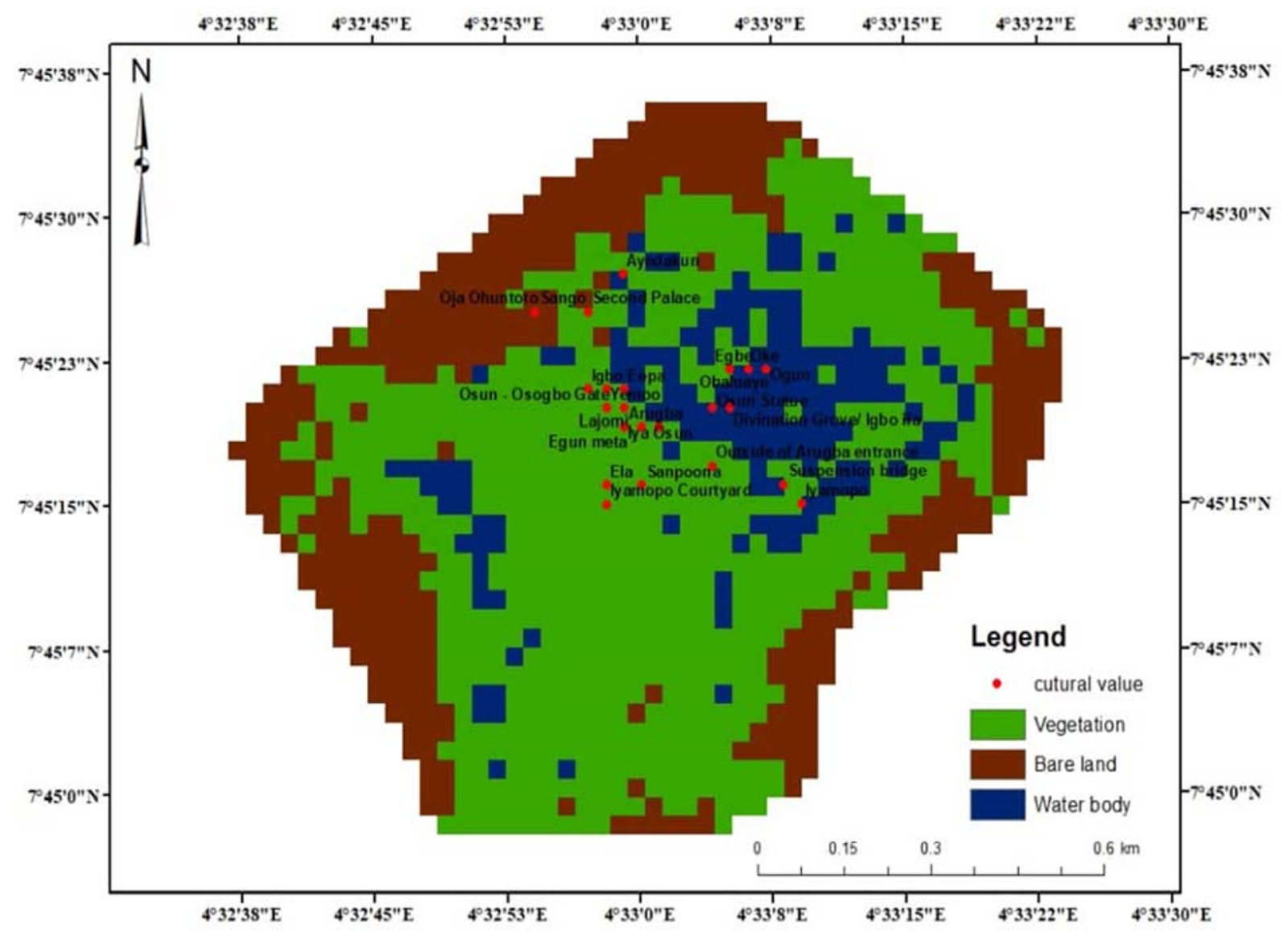

Figure 2. Map of Osun-Osogbo Sacred Grove showing the locations of various cultural values.

Table 4. Location of various cultural values within the grove.

\begin{tabular}{lll}
\hline Cultural value & Latitude $\left({ }^{\mathbf{0}} \mathbf{N}\right)$ & Longitude $\left({ }^{\mathbf{0}} \mathbf{N}\right)$ \\
\hline Yemoo & 7.755556 & 4.549444 \\
Kanmololu & 7.755556 & 4.549722 \\
Opelebapelepo & 7.755556 & 4.549722 \\
Lajomi & 7.755556 & 4.549722 \\
Oguntimeyin & 7.755556 & 4.549722 \\
Pajepolobi & 7.755556 & 4.549722 \\
Arenugbongi & 7.755278 & 4.549722 \\
Eyefodo (Ile eleye) & 7.755278 & 4.549722 \\
Iya Osun & 7.755278 & 4.549722 \\
Sculpture of Osun & 7.755278 & 4.549722 \\
Egun meta & 7.755278 & 4.549722 \\
Osun Priest & 7.755278 & 4.549722 \\
Arugba & 7.755278 & 4.549722 \\
Atupa Olojumerindinlogun & 7.755278 & 4.55 \\
Flying tortoise & 7.755833 & 4.549722 \\
Baba Olorunnisola & 7.755278 & 4.55 \\
Olomoyoyo & 7.755278 & 4.550278 \\
Arugba & 7.754722 & 4.551111 \\
First Palace & 7.756111 & 4.551944 \\
Egbe & 7.756111 & 4.551389 \\
Obaluaye & 7.756111 & 4.551667 \\
\hline
\end{tabular}

\begin{tabular}{lll}
\hline Cultural value & Latitude $\left({ }^{\mathbf{0}} \mathbf{N}\right)$ & Longitude $\left({ }^{\mathbf{0}} \mathbf{N}\right)$ \\
\hline Ogun & 7.756111 & 4.551944 \\
Oke & 7.756111 & 4.551667 \\
Osun Statue & 7.755556 & 4.551111 \\
Igbo Ifa (Divination forest) & 7.755556 & 4.551389 \\
Iyamopo & 7.754167 & 4.5525 \\
Ela & 7.754444 & 4.549444 \\
Iyamopo Courtyard & 7.754167 & 4.549444 \\
Sanpoona & 7.754444 & 4.55 \\
Igbo Eepa & 7.755833 & 4.549167 \\
Oja Ontoto & 7.756944 & 4.548333 \\
Second Palace & 7.756944 & 4.549167 \\
Osun Shrine & 7.755556 & 4.549722 \\
Sango & 7.756944 & 4.548333 \\
Ayedakun & 7.7575 & 4.549722 \\
\hline
\end{tabular}

\section{Discussion}

\subsection{Traditional Norms and Their Effectiveness}

Although hunting in all forms, felling of trees, fishing, farming, pollution of the environment, building of structures 
are taboos within the study area, based on traditional laws and the beliefs of the indigenes, the penalties stipulated through conventional laws are, however, too light to serve as deterrent to potential offenders, and these inadequacies of conventional laws have culminated in the extensive degradation of the buffer zone of the grove, which is covered in the traditional laws guiding the core area. In the grove, felling of trees is a taboo since it is believed that anyone engaging in any form of logging would not come out alive, or might be struck by an unknown spirit. This has been very effective as no sign of logging was observed within the area. In the same vein, hunting signs were not seen, and there are evidences with a large population of white-throated monkeys (Cercopithecus erythrogaster) that always troop out to welcome visitors. There was a clear indication that surrounding communities are clearly defined by their cultures and traditions, and they seem to respect all lay-down norms regarding conservation, which greatly helped in preserving valuable flora and fauna species. This agrees with Jimoh et al [17], who reported the significance of a rich cultural heritage in guiding the utilization of natural resources in southern part of Cross River State in Nigeria.

This finding is also in consonance with the observation of Vegter [11], who opined that customary laws can mitigate most of the problems caused by illegal logging and related activities. The core of the grove, which is considered sacred through traditional norms are strictly protected because people fear the consequences of wraths of the Osun goddess, and other affiliated cultural values are well-respected by the indigenous communities. For instance, people do not fish in the river within the grove because of the belief that the fishes belong to the goddess, and any fish caught from the river will never cook, no matter the efforts and time expended in its cooking, and anyone, who consumes such fish, if cooked, would either die same day, become an imbecile or go insane. This is similar to the report by Akindele [18], who inferred that, the fact that certain wildlife species are believed to be emblem of some clans or descents could make them a priority for conservation in some rural communities of Nigeria. In those areas, where wildlife species are sorespected for their significance, people tend to protect them by all means, either for fear of being negatively affected, or for deriving optimal cultural positivity as well as immediate societal and environmental benefits.

In most rural communities of Osun State, especially within $70 \mathrm{~km}$-radii of the study area, it is generally believed that spirits dwell and operate in wild animals such as bush baby (Galago senegalensis) locally-referred to as Egbere in many parts of the Western Nigeria, pigeon (Eyele) and parrot (Aiyekooto or Odidere) and Boa constrictor (Ere) as well as some valuable species of trees like Okoubaka aubrevillei (locally-called Iginla), Milicia excelsa (trade-named Iroko). There are lots of mysteries associated with most of these wildlife and flora species, which make it extremely difficult to hunt them for delicacies in the state. Some of which are believed to bring bad lucks, and lot of sacrifices needed to be made if hunted, in most of the cases, the costs of those atonements are heavier than the values of the hunted species. On the other hand, most of these wildlife species are IUCNclassified as either endangered, critically-endangered or vulnerable. In those rural areas, most of the evil spirits are believed to reside within Iroko and Iginla, respectively. However, only the Iginla (Okoubaka aubrevillei) has been spared by loggers or wood users as a result of such local or native believe. This aligns with the view of Oates [9], who noted that the survival of endangered species and ecosystem is dependent on local participation and understanding of local population in conservation strategies. According to Caldecott et al. [1] and Hens [19], there is a close relationship between cultural diversity and biodiversity. Thus, traditional knowledge systems is expected to play a crucial role in developing species conservation and management strategies. It is also believed that anyone, who pollutes the Osun River in the grove will face the wrath of the goddess or there would be flood disasters. No one is allowed to go near the river unless to pray to the Osun goddess for blessings, especially for gift of wombs (child bearing). Since it is believed that the Osun goddess cures barrenness, it is cherished so much that no one dare engage in any exploitation in the area since this amounts to stealing from the goddess, who is able to provide children to the barrenness (in customary beliefs).

There is also a traditional belief that anyone, who enters the grove to hunt will not come out alive. It is also forbidding to bring snail, salt, palm wine, millet into the Osun Shrine. There is also a traditional belief that whoever attempt to erect an authorized structure on any part of the forest will face the wrath of the goddess, and even to build after being authorized, the goddess must be appeased with a huge sacrifice, which any offender or trespasser might find too difficult to meet. As a result of the respects for the traditional culture, people abide by the traditional rules and regulations associated with the use of the sacred grove and its management practices. Hence, the traditional norms protect, preserve and conserve the tangible and intangible aspects of the grove. It is believed that the goddess of the River Osun has power to protect, and for those who have faith in the goddess are expected to fear no insecurity. It is also believed that if anyone goes against any of the traditional laws or taboos, the spirit (Osun goddess) deals with the offender. However, going contrary to the rules and regulations only attracts bearable sanctions and fines, going by legal means or conventional laws. Consequently, the buffer to which the effects of cultural beliefs were not considered to be potent have witnessed years of degradation.

Although, the sacred grove is managed by the National Commission for Museums and Monuments (NCMM), which is backed by the NCMM Act CAP 242 Laws of the Federation, 1990 (Decree 77 of 1979), the laws have not been so-respected as much as the traditional norms. The policy is expected to work hand-in-hand with the traditional norms/laws of the grove, fines stipulated in the laws are not sufficient enough to scare any offender. This total compliance to the traditional laws is, perhaps, the reason why the article $8 \mathrm{j}$ of the United Nations Convention on Biological Diversity 
calls for parties to respect, preserve, and apply knowledge and practices of indigenous and local communities relevant for the conservation and sustainable use of biodiversity [4]. This is also buttressed by several authors such as [20-23], that having regards for local cultures and traditions of people may impact more positively on biodiversity conservation. However, Gebreziabher and Soltani [24] viewed that attitudes of people towards conservation may depend more on the tangible and economic benefits derived from such resources. This is not the case with the study area, as people cherished the intangible values and heritage over economic gains and tangible benefits. Popa et al. [25] observed that locally-crafted conservation measures are potent to achieve better result, than conventional laws, which has propensity to alienate the indigenous communities in the management of forest resources. At the national level, the management role lies in the hands of NCMM, while at the state level, the state government and King (the Ataoja of Osogbo). The most effective means is that by the king, who delegate authority to subjects, who are custodians of the traditional cultures.

\subsection{Some of the Cultural Values and Their Significance}

\section{Osun River}

The river drains the grove, and takes its course from the swampy grounds of Igede-Ekiti in the neighbouring Ekiti State of Nigeria, flowing through Ijesha land into Osogbo, where it becomes broader meandering through the sacred grove. Its water (Figure 3) signifies relationship between nature, the spirits of the goddess and human beings, and symbolizing life. The river is thus seen as the 'water of life' and is believed to have healing, protective and fertility powers within the grove area. The fishes in the river are said to be own and used by Osun goddess as messengers of peace, blessings and favour. The custodians offer sacrifices, every year, during Osun-Osogbo Festival in which atonements are made to re-enacts the spiritual connections. And because of the uniqueness of the river, it is traditionally a taboo for anyone to harvest fishes, pollute or desecrate the river, or any of its resources including flora and fauna species since the grove is named after the river, and it is believed that the goddess resides in the river of the grove.

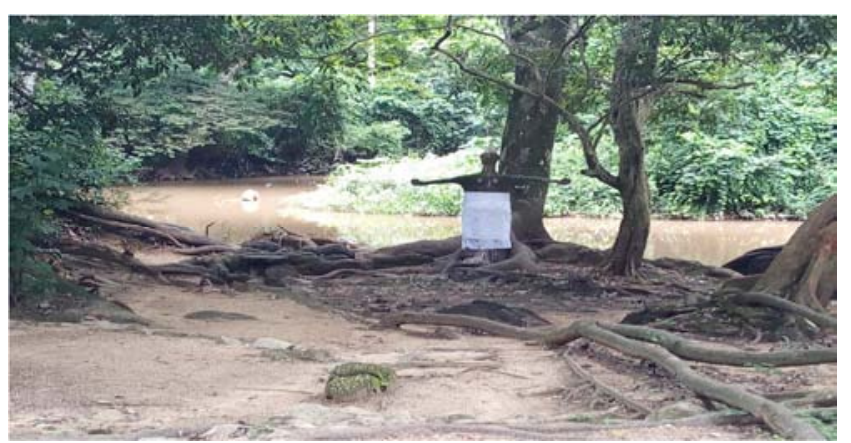

Figure 3. Osun River and statute of her goddess

Ile Osun

Ile Osun (the first palace) is where the first Ataoja of
Osogbo, Larooye and his people first settled (Figure 4). It is located in the Osun courtyard (Agbala Osun), and houses the Osun Shrine and the Temple with the sacred stone stool called Ata. The stone of authority is housed in the temple, which Larooye used some 400 years ago. During the OsunOsogbo Festival, the Osun calabash is placed on the stool. There is the seat of the first king, the current king seats on this stool during the festival to pray for the town, state and the entire nation.

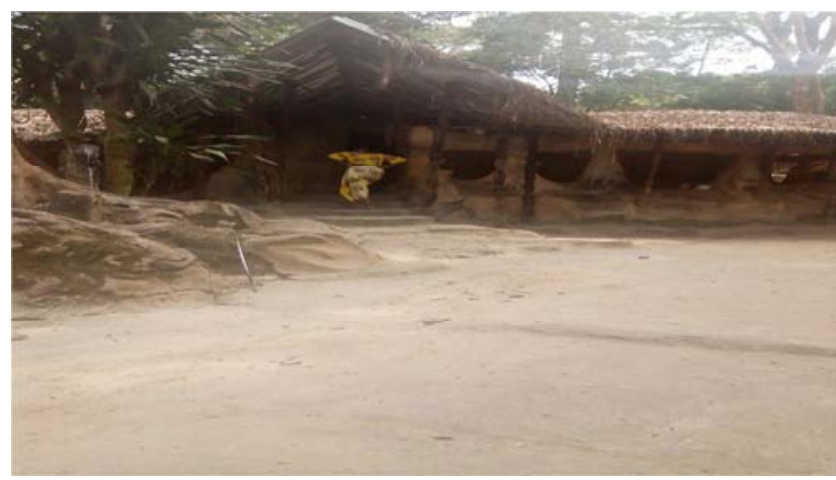

Figure 4. Ile Osun (First Palace).

\section{Iledi Ontoto (Second Palace)}

This sacred palace (Figure 5) was the second residence of Larooye. It is about 600 meters from the first palace. This was built to avoid the effect of constant flooding experience at the first palace. Today the Ogboni Cult House stands within a symbolic reconstruction of the second palace. The Ogboni Cult is an elitist society of men of influence and affluence, similar to European Lodges. Members have their regular meetings at the cult house every 3 traditional weeks (15 days), and daily during the Osun-Osogbo Festival [26].

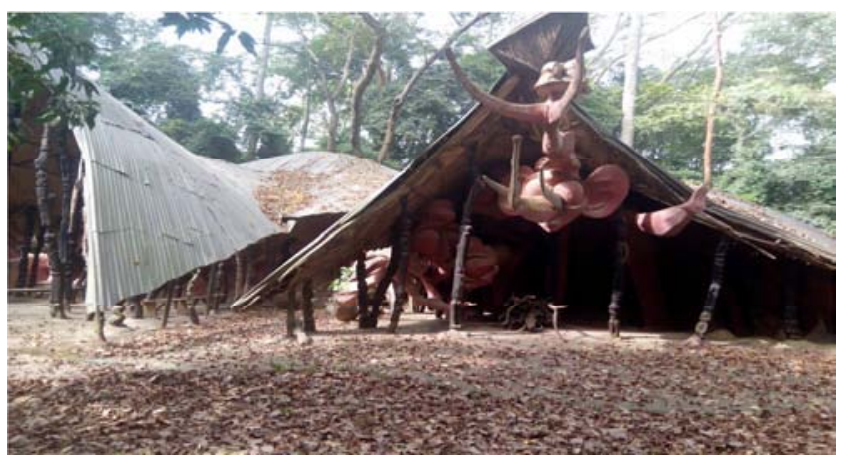

Figure 5. Iledi Ontoto (Second Palace).

\section{Oja-Ontoto}

Oja-Ontoto (Figure 6) is the first market in Osogbo. It is a mythological market, where human and spirit beings are said to have interacted. A traditional shrine (Oja-Ontoto Shrine) is located on its grounds. Evidence of grinding activities is represented by oval pits, out of the Precambrian outcrops of stone slabs that cover the "market space". It is believed that the sprit beings still interact and exchange spiritual valuables at the market, and it is forbidding for traditional novice to intrude. 


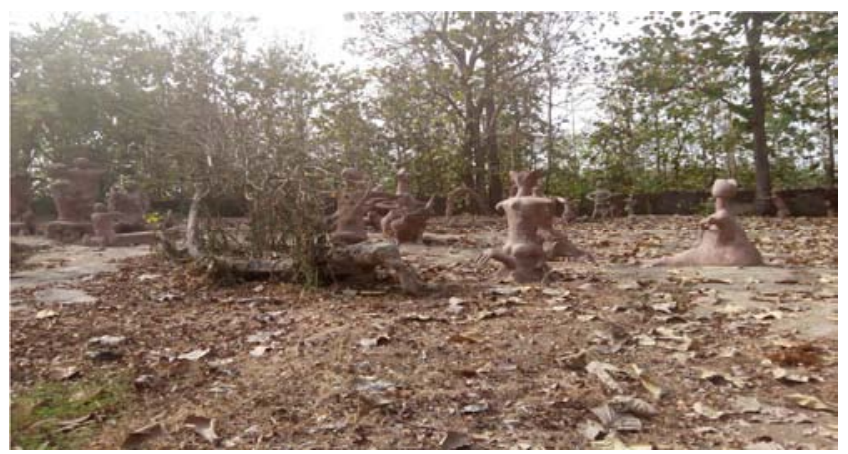

Figure 6. Ontoto Market.

\section{Iyamopo (Goddess of Women)}

Iyamopo is the goddess of women entrepreneurship. She is believed to have magical powers. She also has two messengers, who deliver her messages to the other deities. She is the guard of the grove and chief security officer against any war or any problem or intrusion. She informs the goddess whenever a war or trouble set to emerge. She has three pairs of arms, which are used to perform various feats, depending on what is needed. These arms represent: advice, curse, and blessing. She is believed to have legs, and can also fly with her wings (Figure 7).

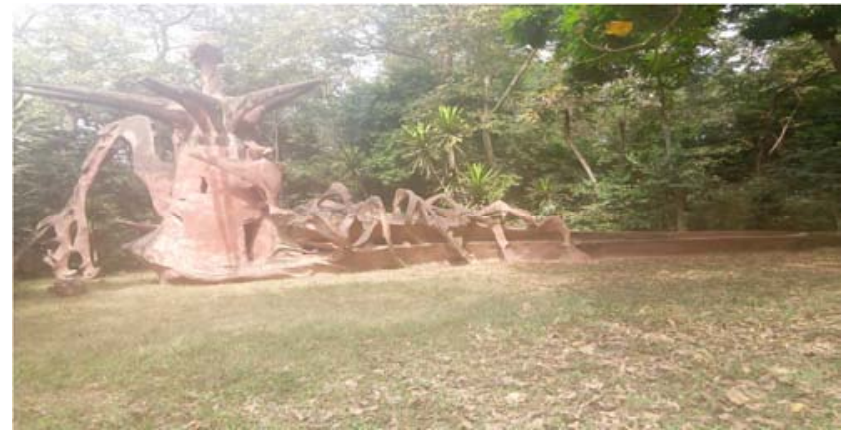

Figure 7. Sculpture of Iyamopo.

\section{Ela}

Ela (Figure 8) is the intermediary between God and man in the grove. He is also known as Orunmila, who is traditionally believed to take prayers to heaven, or to God as an intercessor for man.

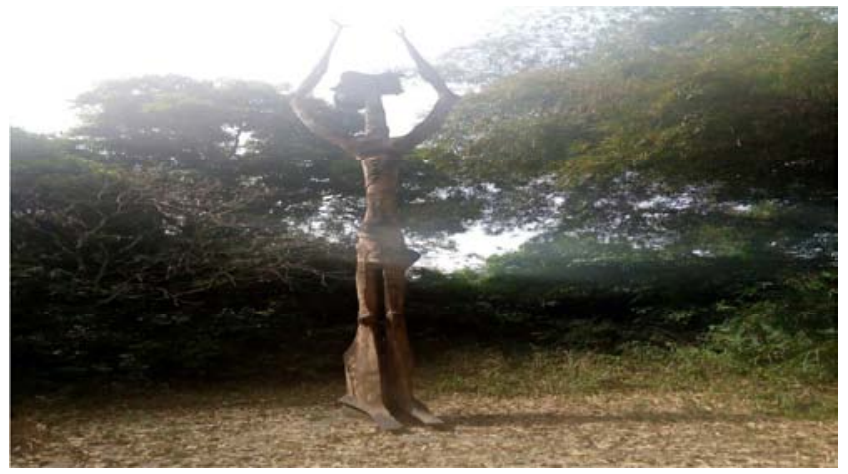

Figure 8. Sculpture of Ela within the grove.

Olomoyoyo
Olomoyoyo (Figure 9), which can be translated to mean woman with many children, is believed to be a goddess of fertility, and delegated by the goddess. When a woman is suffering from barrenness, she is to bring sacrifice, which compose of pap (solid paste made from corn) and traditionally-prepared vegetable called efo yanrin (Launaea taraxacifolia). This sacrifice is placed under the statue of Olomoyoyo (Figure 9). The belief is that the statue represents the god of fertility, bringing sacrifice is therefore to appease the goddess for provision of babies.

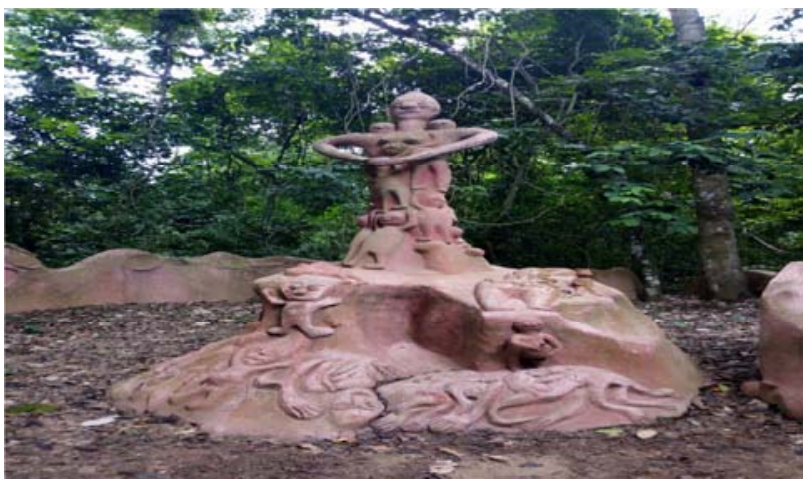

Figure 9. Sculpture of Olomoyoyo.

Atupa Olojumerindinlogun (sixteen-point lamp)

Atupa Olojumerindinlogun (Figure 10) was initially a spirit's lamp (Osanyin), a deity in-charge of healing. The lamp is about $17 \mathrm{~cm}$ high with sixteen lamps points on it. It is believed that both Larooye and Timilehin found the lamp in the forest, when they first settled at Ontoto, which is now a street in the present day Osogbo.

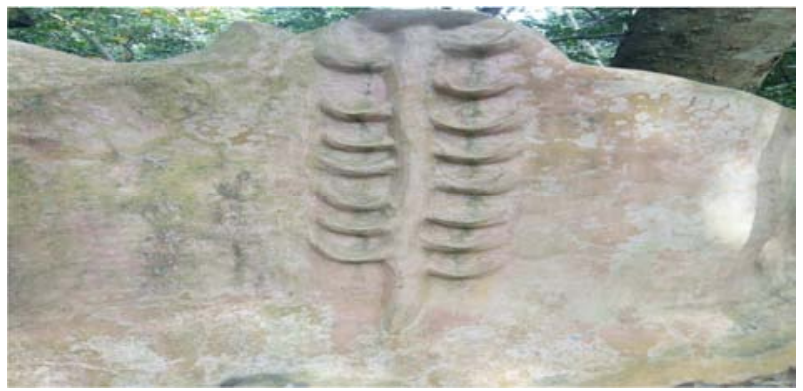

Figure 10. Sculpture of Atupa Olujumerindinlogun.

\section{Conclusion}

This study examined the potency and effectiveness of traditional laws and beliefs in biodiversity conservation in Osun-Osogbo Sacred Grove. The study has shown that, for fear of being struck and killed by unknown spirits, activities like felling of trees, farming, pollution, building of structures, killing of animals in the grove have become taboos, both for the indigenes and strangers. These have helped in the conservation of fauna and flora species of importance. For instance white-throated monkey is very prevalent with no signs of threat to their survival. This species is easily sighted, and with an impressive population due to the belief that those animals belong to the goddess of Osun River, and the penalty 
for exploiting any of them is death or chronic insanity, with no remedy. All the taboos are obeyed, and this has contributed immensely to the protection and conservation of numerous wildlife and tree species in the area.

It was, however, observed that areas not covered by the traditional laws of the indigenous people (buffer zone) were badly degraded, despite the conventional policy and laws, which stipulated fines and sanctions for offenders or trespassers. Therefore, it was clear that enforcing conservation laws and regulations would yield no result, except such laws and regulations are in tandem with cultural milieu of the people, whose original lands were constituted into conservation areas, or protected areas, as the case may be. It can be inferred that, indigenous people have impressive regards for own-laws and regulations with regards to conservation. Hence, it becomes very expedient to involve local people in all conservation efforts, and to always have much regards and considerations for their cultures in formulating any virile conservation strategy. Instead of viewing local cultures and traditions as archaic, it is profitable to adopt relevant principles in specific cultures, and modify them for such purpose as effective conservation means.

Thus, there is urgent need to sensitize nature conservation stakeholders on the relevance of culture, belief and traditions and how to manage them for mutualism since indigenous people find it very difficult to break own-traditions than the conventional laws or judicial proceedings. It is suggested that this laudable respects for traditions be strengthened by finding what would be respected as a means of conservation in most protected areas of Nigeria, especially the tropical rainforest zones in the southern parts, where most protected areas only exist on paper, but already-gone in reality. Doing so may engender most forest communities to conservation and protection of important areas and valuable fauna and flora species. This cannot, however, succeed without the involvement of local communities and indigenous people in forest resources management and conservation.

\section{Acknowledgements}

The authors are grateful to the National Commission for Museums and Monuments for permission and their supports. Special thanks to the Ataoja of Osogbo Land and his subjects, especially the custodians, who assisted in various ways during fieldworks. The staff of the grove are sincerely appreciated for deep understanding, tolerance and guidance.

\section{References}

[1] Caldecott, J., Mills, L. and Nelleman, C. (2005). Challenges to great ape survival. Pages 217'234 in J. Caldecott, and L. Mills, editors. World atlas of great apes and their conservation. University of California Press, Los Angeles, California, USA. Traditional Knowledge Systems and the Conservation of Cross River Gorillas: a Case Study of Bechati, Fossimondi, Besali, Cameroon. Ecology and Society 16 (3): 22-36.

[2] Taylor, E. B. (2000). Primitive Culture, London, African
Civilizations; origin, Growth and Development. Lagos, Nigeria: UTO Publications.

[3] Etiendem, D. N., Hens, L. and Pereboom, Z. (2011). Traditional Knowledge Systems and the Conservation of Cross River Gorillas: a Case Study of Bechati, Fossimondi, Besali, Cameroon. Ecology and Society 16 (3): 22-36.

[4] United Nations Convention on Biological Diversity (UNCBD). (2007). Pachamama: a traditional knowledge newsletter of the Convention on Biological Diversity. CBD 1. www.cbd.int/doc/newsletters/news-8j-01-low-en.pdf.

[5] Leach, E. R. (2000). Political system of Highland Burman London; African Civilization; Origin, growth and development, UTO Publications.

[6] Probst, P. 2011. Osogbo and the Art of Heritage: Monuments. Deities, and Money. Bloomington: Indiana University Press.

[7] Gustavo, S. M. A. and Jonathan, R. R. (2012). Protected Areas and Local Communities: an Inevitable Partnership toward Successful Conservation Strategies? Ecology and Society 17 (4): 14-29.

[8] Quang, T. N. Q., Chinh, N. V. and Hanh, V. T. (2008). Statutory and Customary Forest Rights and their Governance. The Case of Viet Nam. International Union for Conservation of Nature in Viet Nam, IUCN. 44 pp.

[9] Oates, J. F. (1999). Myth and reality in the rain forest: how conservation strategies are failing in West Africa. University of California Press, Berkeley, California, USA.

[10] UNESCO. (2005). Convention on the protection and promotion of Diversity of Cultural Expressions, UNESCO, Paris.

[11] Vegter, A. A. (2005). Forsaking the Forests for the Trees: Forestry law in Papua New Guinea inhibits Indigenous Customary Ownership. Pacific Rim Law \& Policy Journal 14 (2): 545-574.

[12] National Commission for Museums and Monuments, NCMM. (2010). Osun-Osogbo Sacred Grove, UNESCO world heritage site 2010-2014, conservation management plan.

[13] IUCN. (2003). Recommendations of the Vth IUCN World Parks Congress in Durban, South Africa, 2003. 200 pp.

[14] Ola, A. B. and Adewale, Y. Y. (2014). Infrastructural Vandalism in Nigerian Cities: The Case of Osogbo, Osun State. Journal of Research on Humanities and Social Sciences 4 (3): 49-60.

[15] Adebisi, L. A. (1999). Biodiversity of selected sacred groves in Osun state, Nigeria Ph.D. Thesis submitted to Department of Forestry, University of Ibadan.

[16] Olatunbosun, O. (2012). What You Did Not Know About Osun Osogbo, Travel and Tourism Viewpoint, Bureau of Communication and Strategy, Governor's Office, State of Osun.

[17] Jimoh, S. O., Ikyaagba, E. T., Alarape, A. A., Obioha, E. E. and Adeyemi, A. A. (2012). The Role of Traditional Laws and Taboos in Wildlife Conservation in the Oban Hill Sector of Cross River National Park (CRNP), Nigeria. Journal of Human Ecology 39 (3): 209-219.

[18] Akindele, S. O. (2010). Forest Restoration through Traditional Institutions in Nigeria: Challenges and Prospects. http://www.cfc2010.org/papers/session13Akindele-s13.pdf > (Retrieved January 2, 2019). 
[19] Hens, L. (2006). Indigenous knowledge and biodiversity conservation and management in Ghana. Journal of Human Ecology 20 (1): 21-30.

[20] Anoliefo, G. O. (2015). Influence of Traditional Taboo Practices on Natural Resource Conservation in Uli, Ihiala Local Government Area of Anambra State Nigeria; Sustainable Community Development. Journal of Sustainability 4 (4): 1-14.

[21] Rim-Rukeh, A., Irerhievwie, G. and Agbozu, I. E. (2013). Traditional beliefs and conservation of natural resources: Evidences from selected communities in Delta State, Nigeria. International Journal of Biodiversity and Conservation 5 (7): 426-432.

[22] Taubert, B. and Pretzsch, J. (2007). Cultural influence of forest perception and forest use among the Tiriki community in West Kenya. Tropentag 2007 University of KasselWitzenhausen and University of Göttingen, October 9-11. 7pp.

[23] Customary Law in Forest Resources Use and Management. A Case Study among the Culture Identity and Resources Use Management, CIRUM. (2012). Dzao and Tai People in NoerthWest Vietnam. Culture Identity and Resources Use Management (CIRUM), International Work Group for Indigenous Affairs (IWGIA) and Asia Indigenous Peoples' Pact (AIPP). 46 pp.

[24] Gebregziabher, D. and Soltani, A. (2019). Exclosures in people's minds: perceptions and attitudes in the Tigray region, Ethiopia. Forest Policy and Economics 101: 1-14.

[25] Popa, B., Daniel, M., Aureliu, N. and Hălăli an, F. (2019). Intentions to engage in forest law enforcement in Romania: An application of the theory of planned behaviour. Forest Policy and Economics 100: 33-43. 